\title{
A Role of Bovine Cardiac Myosin-Hydrogel Polymere to Accelerate Wound Healing of Autograft Skin in Rabbits
}

\author{
Ibrahim MH Alrashid ${ }^{1}$, Shireen $\mathbf{J}_{\text {Khaleel }}^{2}$ \\ ${ }^{2}$ Department of Surgery and Obestetric, University of Basrah/ Basra / Iraq \\ ${ }^{2}$ Department of Anatomy and Histology / College of Veterinary Medicine / University of Basrah/ Basra / Iraq
}

\begin{abstract}
The present study were showed more developed in $2^{\text {nd }}$ and $3^{\text {rd }}$ treated groups compare with control and $1^{\text {st }}$ trated groups which were treated by bovine cardiac myosin-hydrogel polymer in three concentration $25 \%, 50 \%$ and $75 \%$, while control group treated with gentamicine and hydrogel only, gross pictures were showed similar in all groups at 1-3 days after surgery, $2^{\text {nd }}$ and $3^{\text {rd }}$ groups were loss scar tissue above wound and wound line were showed until 9 days in $3^{\text {rd }}$ treated group, while wound line in $2^{\text {nd }}$ group were disappeared until to 10-13 days after surgery. Histopathological changes is very important to evidence the bovine cardiac myosinhydrogel was effect to accelarete wound healing and speed recovery, collagen and fibers matrix in histopathology slides reveal to speed healing and the role of bovine cardiac myosin in wound healing, in conclusion the bovine cardiac myosin is highly effect in wound healing, in recommended; to more study in this protein specially biochemical study and cytologyical study to knowledge the main elements whose play roles in wound healing.
\end{abstract}

Keywords: bovine myosine, polymere, hydrogel, wound healing, cardiac myosine

\section{Introduction}

Bovine cardiac myosin $(\mathrm{BCM})$ is a complex protein that is regarded to the superfamily prototype of motor protein (1), converts chemical energy in adinotriphosphate (ATP) to motor mechanical energy, thus generate forces and movements (2). BCM is a protein which extract from cattle heart and the calves have lage large quantity of myosin (3). Superfamily of myosin include myosin I, myosin II, myosin III, myosinIV, myosinV, myosin VI, and other type of myosin that related with main types of myosin such as myosin binding protein (MyBP) which subdivided into two types include MyBP-C and MyBP-H(1 1nd3 ). One of the best charesterstic properties of MyBP is its relatively strong affinity for actin protein (4), and react with $\mathrm{C}^{2+}$ to form force generation after $\mathrm{C}^{2+}$-activiation which stimulate ATPase that convert chemical energy to movement the molecular motor $(5,6)$. Myosin is a hexapolypeptide constituted by light and heavy chain the isoform of which segregate in bovine cardiac is polypeptide with molecular mass of about 20-200 kilodalton (KD) (7). Association the complex reaction of wound healing is calmodulin $(\mathrm{CaM})$ that is highly react with $\mathrm{C}^{2+}$. Calmodulin ( $\mathrm{CaM}$ ) found in all eukaryotic cells are multifunctional $\mathrm{C}^{2+}$-binding regulatory protein that mediates many $\mathrm{C}^{2+}$-related cellular events (9). Re-vascularization and vascular permeability are occasionally depend on myocin phosphorylation and calcium $\mathrm{C}^{2+}$ - calmodulin CaM activation to stimulate myosin chain bioactivity in permeablized endothelium, ATP activity, and $\mathrm{C}^{2+}$ motion, these processes are called myosin chain phosoryltion (MCP) are absolute requirements for bio-reaction and intercellular gap formation in the wound (10). The activity of myosin motor is modulated by phosphorylation of regulatory myosin chain kinase and phosphotase (11). Myosin ligand-based $\mathrm{C}^{2+}$ signaling may important in fibroblast-mediated wound repair, but the mechanism supporting transiet changes in $\mathrm{C}^{2+}$ are unkown (11). Magnesium $\left(\mathrm{Mg}^{+2}\right)$ play an important role in myosin bioactivity, ATPase activity of myosin is activated by $\mathrm{C}^{2+}$ at millimolar rang (12), the high rate of ATP hydrolysis by myosin in the presence of millimolar $\mathrm{C}^{2+}$, therefore stimulate $\mathrm{Mg}^{+2}$-ATPase to chelate structure involving the two sulfohydral sits (H1 sit and $\mathrm{H} 2$ sit) of myosin protein (8). Myosin activity regulates cells migration, these dynamic of cells migration signals through proteaseactivited receptors (Par1 and Par2) such as epidermal growth factor (EGF), platelet-drived growth factor (PDGF), vascular endothelial growth facor (VEGF) (13). Actinactivited ATPase is stimulated when myosin regulatory light and heavy chains are phosphorylated by Myosin kinase(14).

Hydrogel is polymeric materials, that is hydrophilic structure of which capable to holding large amount water in their three-dimensional networks (15), it ability to absorb water arises from hydrophilic function attached to the polymeric backbone (15). Most researches were documented the hydrogel didn't effect on the process of wound healing, except burn wound healing due to the hydrogel have large amount of water to moist the burn area and prevent the infection (16).

Cutaneous wound injery, a series of coordinated events occurs include bleeding, coagulation, acute inflammation, cells migration, proliferation and protein synthesis as well as remodeling of extracellular matrix (17), cutaneous skin mesenchymal stromal cells(MSCs) regulate immune and inflammatory reseponces and enhance cutaneous wound healing (17). Cutaneous wound healing is a complex and well orchesteated biological process requiring the coordinated migration and profiliration of both keratinocytes and fibroblasts (18). $\mathrm{Ca}^{+2}$ play main role in wound healing process via intracellular- $\mathrm{Ca}^{+2}$ concentration channels (19), that promote wound healing as well as that is related with myosin phosphorylation (19). Several factors 


\section{International Journal of Science and Research (IJSR) \\ ISSN (Online): 2319-7064 \\ Index Copernicus Value (2015): 78.96 | Impact Factor (2015): 6.391}

affects on the process wound healing such as oxygenation, infection, sex hormones and stress factors as well as corticoid steroids drugs (20).

\section{Materials and Methods}

\section{Bovine Cardiac Myosin Preperation}

\section{Extraction and Isolation}

Bovine cardiac myosin extract was describe by Feuer et al. and Spudich et al. (21), these method was called Acetone Powder Myosin Extraction, calf hearts were brought at abattoir from fresh sloughted calves, right and left ventricals were sperated from other parts of heart, packed in ice box in 30 minutes of death, these tissues were then cut into small pieces and stored in a thin layer papers at $-15 \mathrm{C}^{\circ}$ within $2 \mathrm{hr}$ in freez. A $400 \mathrm{~g}$ meat batch was removed from the freezer, quickly chopped, and minced meat while still frozen and wash in 1.5 liters of $0.1 \mathrm{M} \mathrm{KCl}$ for 10 minute with continuous strring at $4 \mathrm{C}^{\circ}$ to digest the minced meat (23). The residue was collected in fine nylon gauze over a Büchner filter flask and rewashed in 1.5 liters of $0.1 \mathrm{M} \mathrm{KCl}$ for 10 minutes, these procedure was repeated in 1.5 liters of $50 \mathrm{mM}$ Sodium Bicabonate for 7 minutes within 1.5 liters 1 mM EDTA for 7 minutes, after than rewashed 2 minutes in 1.5 liters of fresh water at $4 \mathrm{C}^{\circ}$ were performed and care was taken to remove as much of the water prior to extraction in acetone at $20 \mathrm{C}^{\circ}$, a $50 \%$ of aceton concentration in the picese, 2.5 liters volume of acetone was made ready in a beaker and the residue was crumbed by manual hand in a second beaker, the acetone was add rapidly within 10-20 second only, the residue was extract through clean nylon gauze over Büchner filter flask, finally the residue was quickly air dried with fan (22). Pic (1)

Picture (1) diagrammatic procedure of preparation of myosin

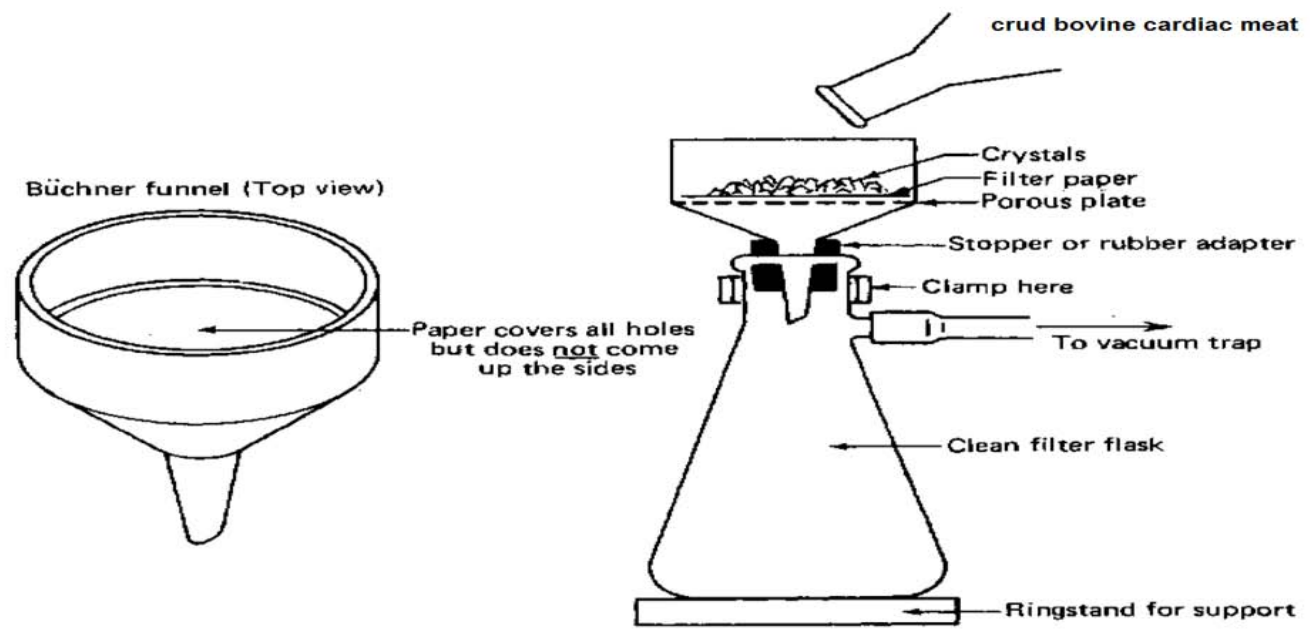

\section{Purification}

Bovine cardiac myosin was purified at $6.5-7.0 \mathrm{PH}$ in $1 \mathrm{mM}$ Di-Thio-Threitol (DTT) ${ }^{*}$ and $50 \%$ glycerol at $20 \mathrm{C}^{\circ}$, further purification by protolytic degradation products of cadiac myocin (50 klotz)

\section{Identification}

To ensunce and more identification was tested by sepharose gel filteration electrophorsis (24).

\section{Hydrogel Preparation}

The hydrogel was synthesis from starch, the main process of this procedure is mixing of starch and water, inserting with acrylonitrile, separation and drying followed by saponification with alkali at $95 \mathrm{C}^{\circ}$ for $1 \mathrm{hr}$, precipitation with methanol, washing with water free ethanol, and drying under vacuum at $60 \mathrm{C}^{\circ}$ for $3 \mathrm{hr}$. A redox system $\left(\mathrm{Fe}^{+2} /\right.$ $\mathrm{H} 2 \mathrm{O} 2$ ) has been employed as a source $\left[\mathrm{OH}^{-}\right]$free radical. Acrylonitrile (AN) / starch $=1.4$, oxygen peroxide $(\mathrm{H} 2 \mathrm{O} 2)$ $1.2,1.5 \mathrm{~g}$ starch. $\mathrm{H} 2 \mathrm{O} 2 / \mathrm{FeSO} 4.7 \mathrm{H} 2 \mathrm{O}=6(\mathrm{w} / \mathrm{w})$, liquidsold $=10-1$, grafting temperature $30 \mathrm{C}^{\circ}$, grafting time 90 min., saponification time $90 \mathrm{~min}$. , $9 \mathrm{ml} \mathrm{NaOH}(0.7 \mathrm{~N}) / \mathrm{g}$ grafting starch, saponification temperature $95 \mathrm{C}^{\circ}$, methanol precipitation and washing $(20 \mathrm{ml} / \mathrm{g}$ grafting starch), water and drying temperature $60 \mathrm{C}^{\circ}$, and drying tim $3 \mathrm{hr}$. (25). The procedure is summarized by diagram pic. (2) 
International Journal of Science and Research (IJSR)

ISSN (Online): 2319-7064

Index Copernicus Value (2015): 78.96 | Impact Factor (2015): 6.391

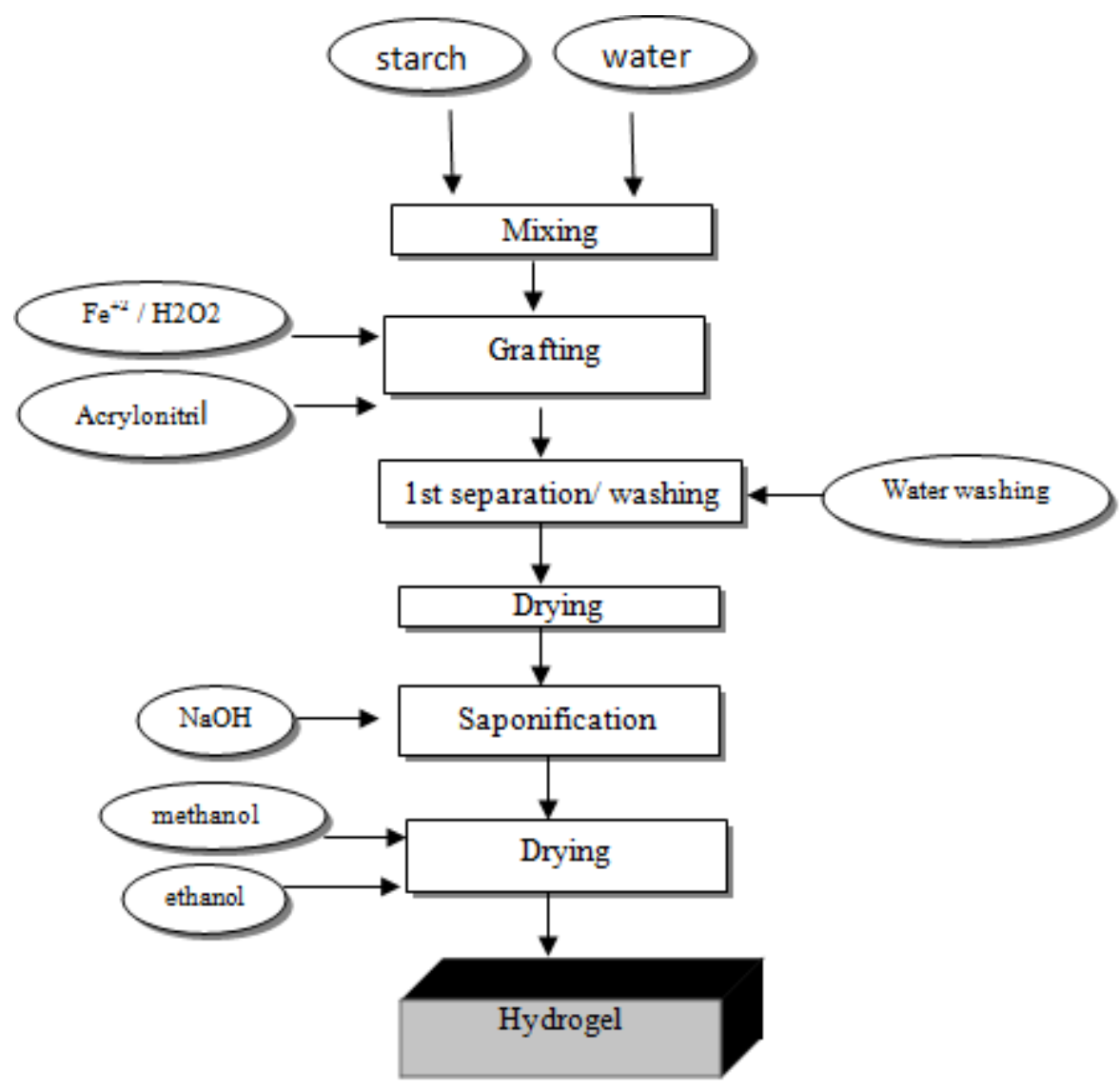

\section{Myosin-Hydrogel Polymerization}

Myosin protein after preparation with asptical technique was mixed with hydrogel polymer, packaging with sterial Picture (3) myosine-hydrogel tubes with different container, the ratio according experimental design $(\mathrm{W} / \mathrm{V})$ and concentration kept under $20 \mathrm{C}^{\circ}, \operatorname{Pic}(3)$

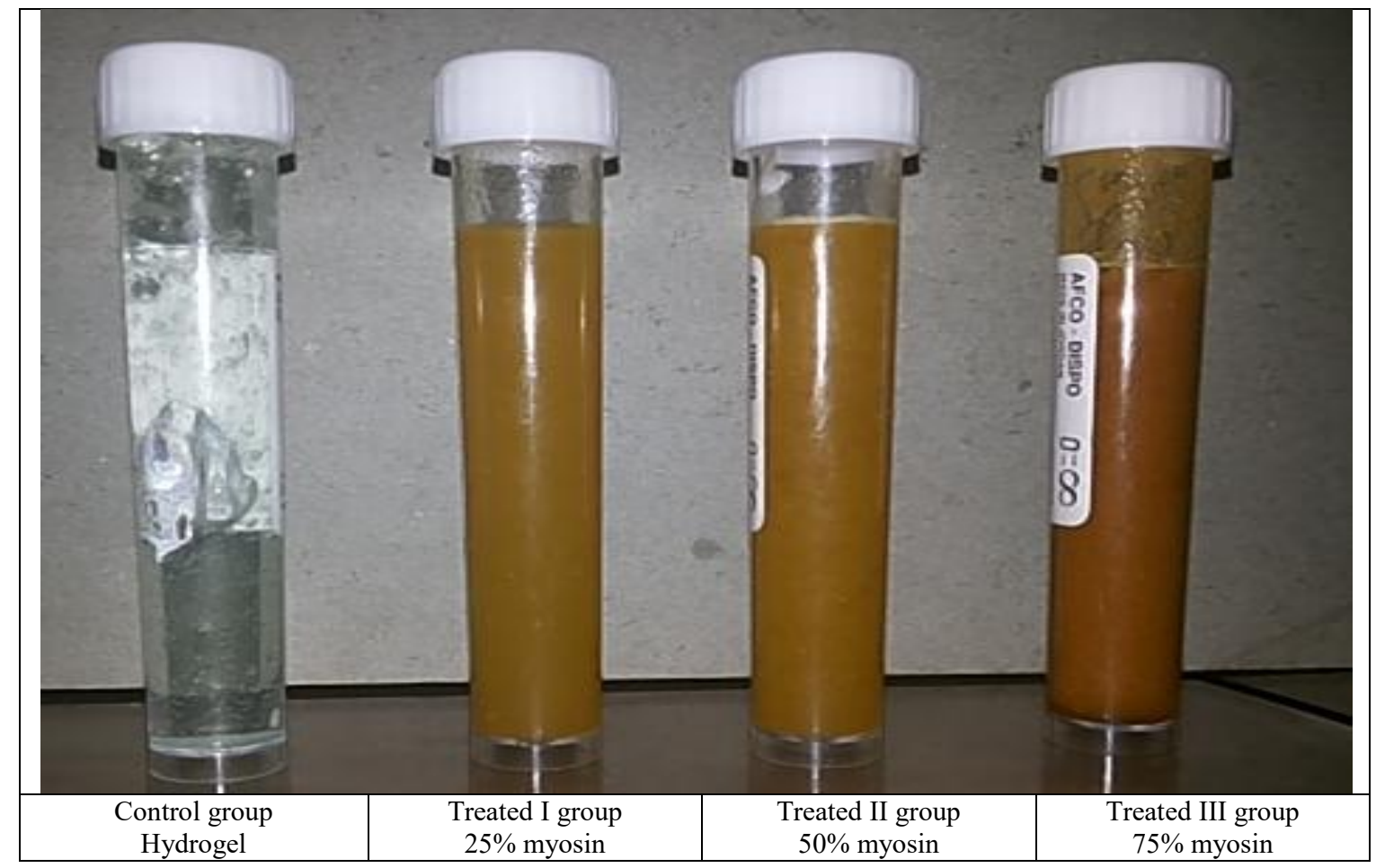

Animals

In the present study, thirty two rabbis were used (Lepus cuniculus), same genera (male), age $7 \pm 2$ months, one in similar condition and fed with bread and hay, which were divided into four groups, according to the experimental design.

\section{Volume 6 Issue 1, January 2017 www.ijsr.net}


International Journal of Science and Research (IJSR)

ISSN (Online): 2319-7064

Index Copernicus Value (2015): 78.96 | Impact Factor (2015): 6.391

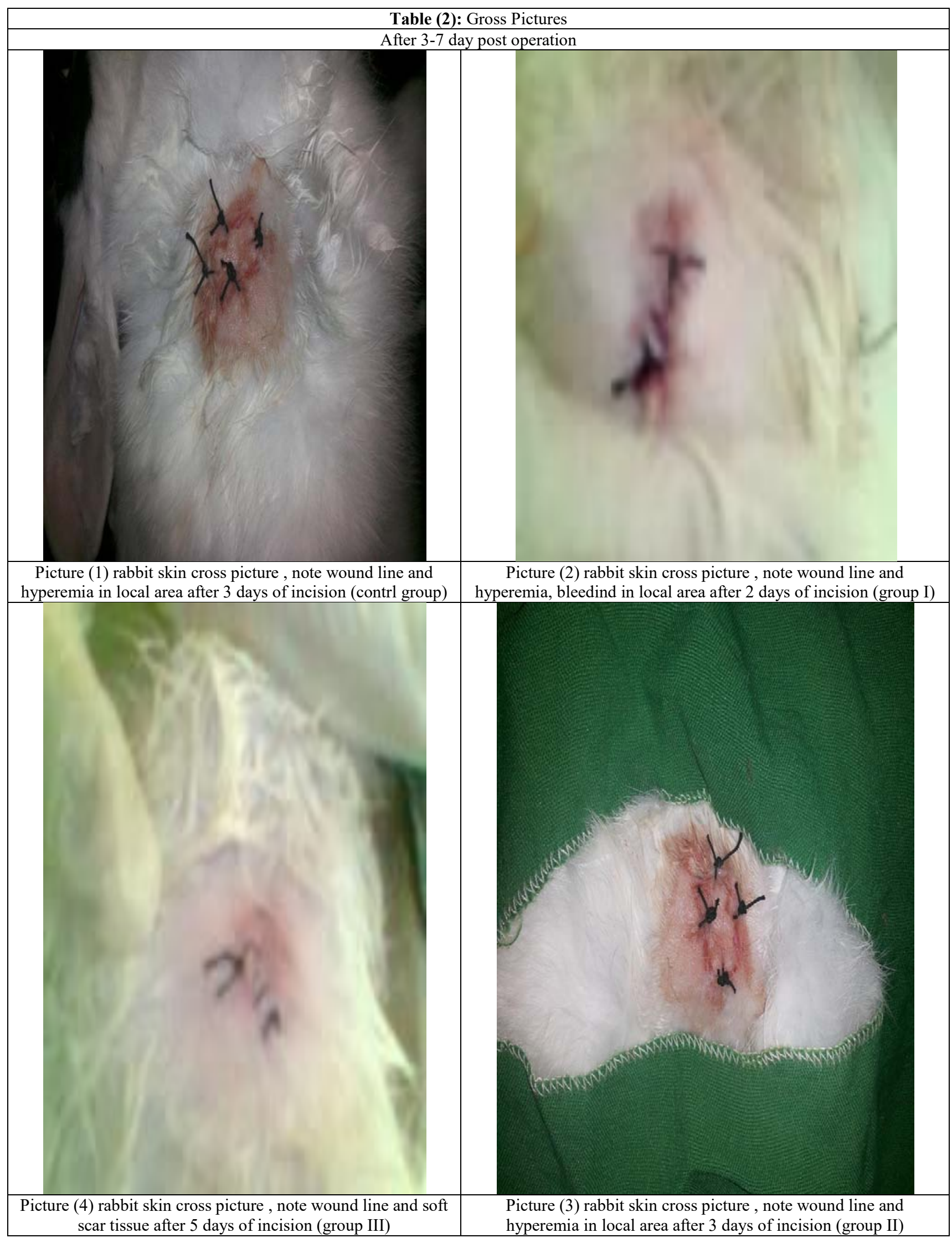

Volume 6 Issue 1, January 2017

www.ijsr.net

Licensed Under Creative Commons Attribution CC BY 


\section{International Journal of Science and Research (IJSR) \\ ISSN (Online): 2319-7064}

Index Copernicus Value (2015): 78.96 | Impact Factor (2015): 6.391

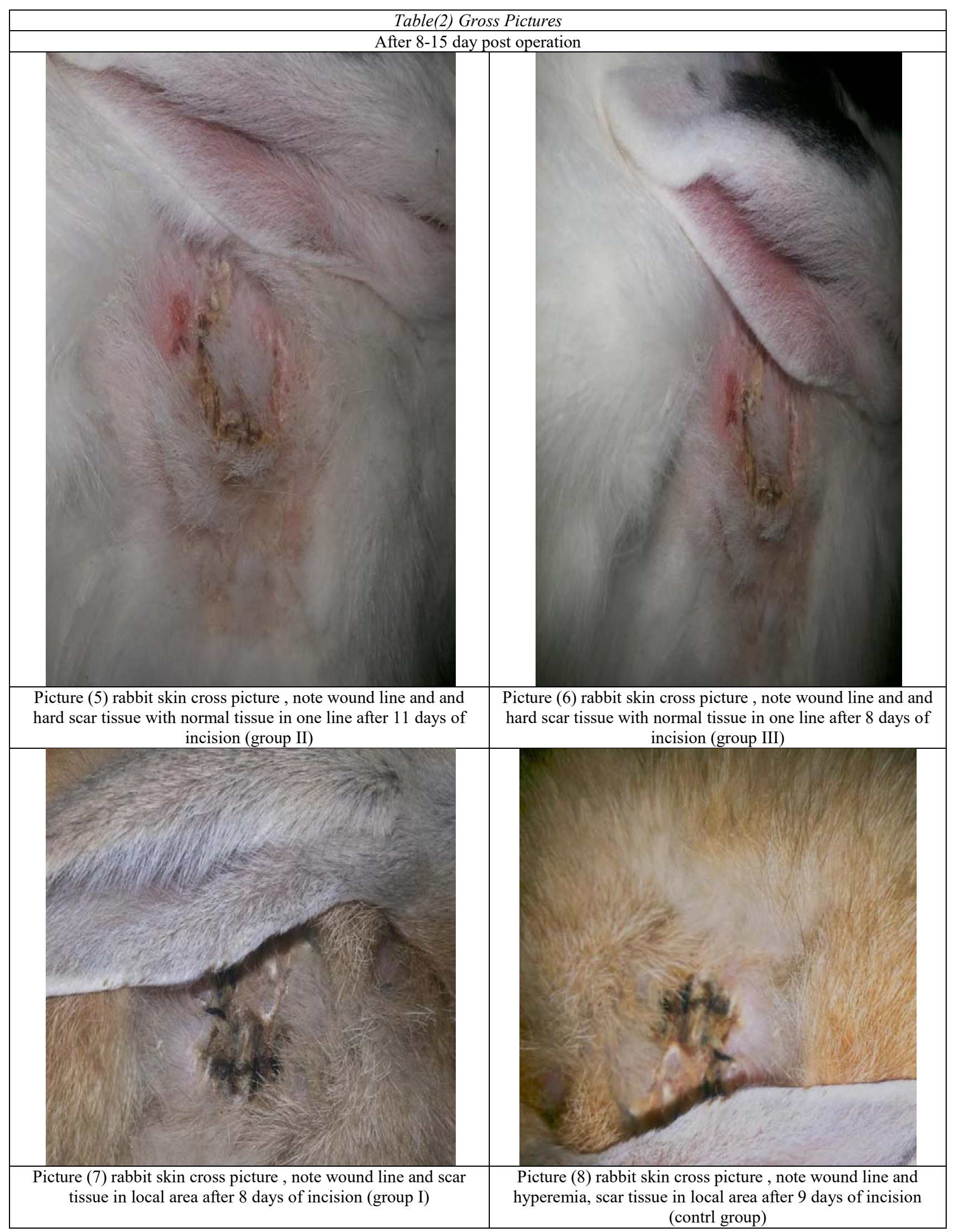

\section{Histopathological Picture Exammination}

Parameters skin wound tissues changes accordingly the polymers consists with bovine cardiac myocine. The changes occurs in wound edges and wound hole. The skin with scar formation filled with necrotic debris, fibrin and vascularized granulation tissue consisting myofibroblast and immature capillaries. Table (3;a,b,c,d) shows histopathological changes amonge groups of treated animals.

Volume 6 Issue 1, January 2017

www.ijsr.net

Licensed Under Creative Commons Attribution CC BY 
International Journal of Science and Research (IJSR)

ISSN (Online): 2319-7064

Index Copernicus Value (2015): 78.96 | Impact Factor (2015): 6.391

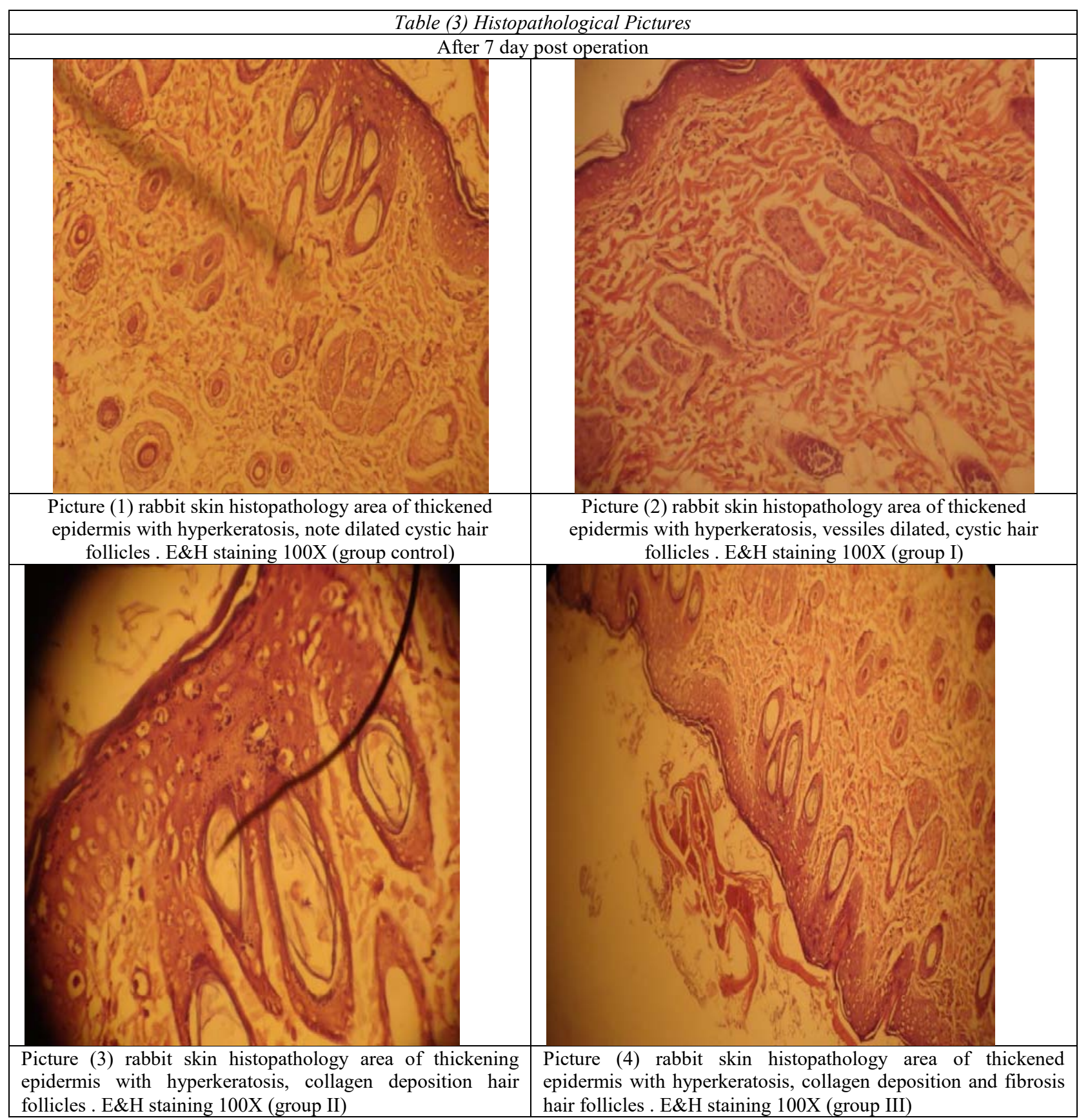

Volume 6 Issue 1, January 2017

www.ijsr.net

Licensed Under Creative Commons Attribution CC BY 


\section{International Journal of Science and Research (IJSR)}

ISSN (Online): 2319-7064

Index Copernicus Value (2015): 78.96 | Impact Factor (2015): 6.391

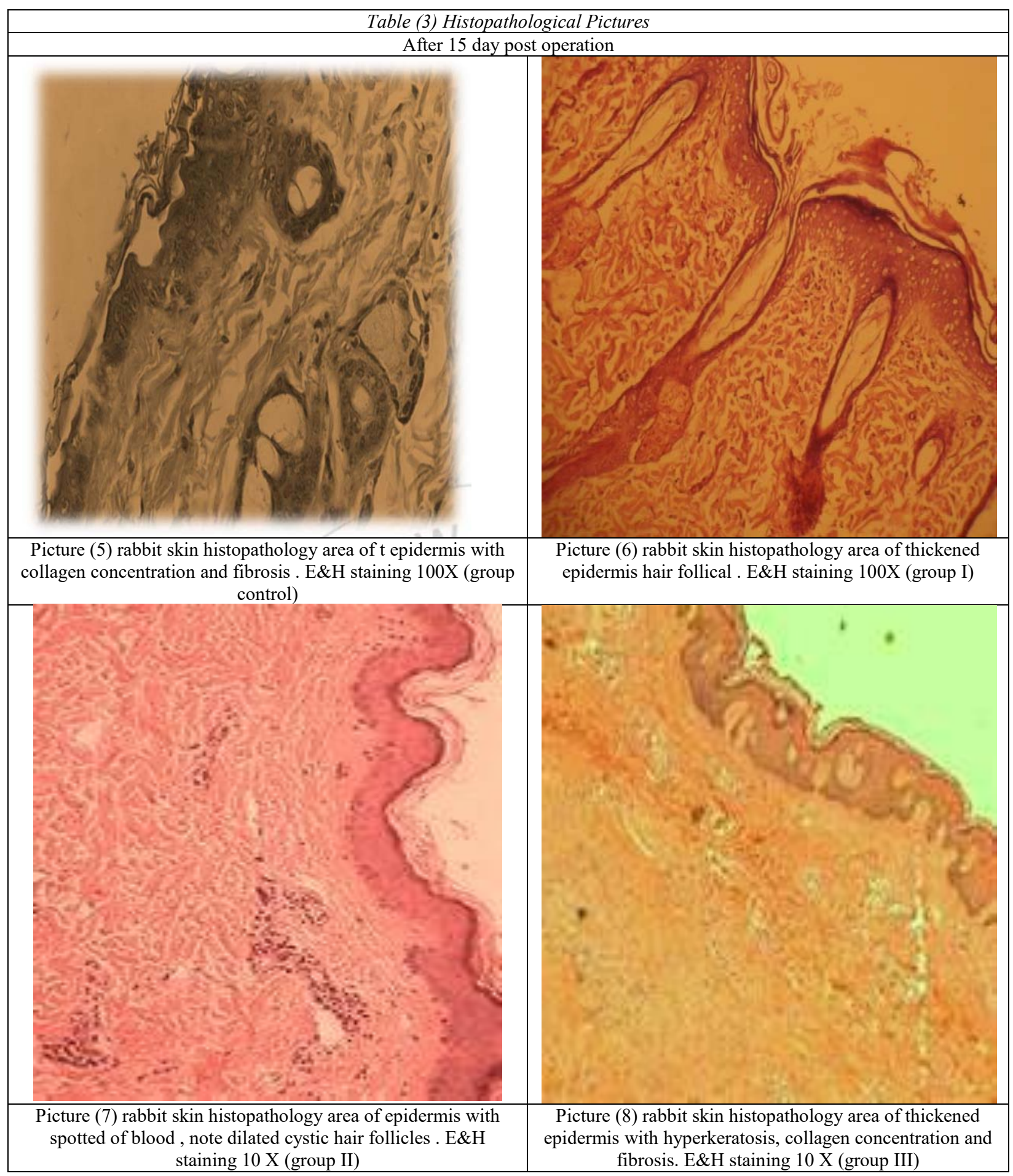

\section{Discussion}

Wound healing is a serious reaction include local rection and systemic reaction with multiple phases eg. hematoma, coagulation, inflammation, collagenation, fibroblast, myoblast migration as well as anti-inflammatory, intibiotic and other drugs may be accelerate or inhibit the processes wound healing (30). The present study indicate desirable systemic reaction, means the bovine cardiac myosin polymer has positive effect in skin wound healing, there weren't similar study to compare with present study, therefore should be succeeded the effect of myosin in wound healing dynamic. Surgical wound of skin graft was done under aseptic technique and remove the patch and re-suture at same anatomical situation are the edges of wound and two surfaces; cutaneous and cutaneous muscles, the first step of wound healing was hematoma and inflammatory phase. Hematoma includes RBCs and other inflammatory cells (TGF- $\beta$, PDGF, FGF, EGF, T-lymphocytes and other inflammatory cells), the reaction between bovine cardiac myosin polymer-hydrogel and inflammatory cells lead to increase inflammatory amount in the surgical area to the threshold pike, as well as initiate wound healing. Excess blood supply and local area temperature, gross pictures and microscopic pictures at 1-3 days post surgery (31). The metabolism of myosin by enzymatic ATPase, cAMG and myosin chain kinase, the phosphorylation of myosine product polypeptide, calmodulin and considerable ATPafter absorbtion and ooze the hematoma containt (32). The gross

\section{Volume 6 Issue 1, January 2017 www.ijsr.net}




\section{International Journal of Science and Research (IJSR) ISSN (Online): 2319-7064 \\ Index Copernicus Value (2015): 78.96 | Impact Factor (2015): 6.391}

pictures at 1-3 day post surgery and treatment don't appear clearly at different groups except in $2^{\text {nd }}$ and $3^{\text {rd }}$ treated groups were show more excessive soft scar tissue tend to redness. In debridement phase and invasion of mesenchymal cells, collagen, fibroblast cells, myoblast cells and progenic revascularisation; the differentiation, proliferation and migration of stromal cells depending on biological catalysts. Bovine cardiac myosine after phosphorylation release high energy ATP, therefore the re-epitheliazation occurs quickly and more collagen receipted with fibroblasts (33). The evidence to the role of myosin phosphorylation and product energy and increase biological processes were showed in microscopic picture $2^{\text {nd }}$ and $3^{\text {rd }}$ treated groups, there were more collagen and fibers, $1^{\text {st }}$ treated group no evidence to change in collagen and fibers of control group. Gross pictures of $2^{\text {nd }}$ and $3^{\text {rd }}$ treated groups were shown after 5-9 days after surgery more development, after 10 days the line of wound in $3^{\text {rd }}$ group were disappearing completely, due to the rection calmodulin and $\mathrm{Ca}^{2+}$ with ATP those enhanced local stem cells in cutaneous wound healing and tissue regeneration at 7 days after treatment of surgical wound (34). Calcium ions $\mathrm{Ca}^{2+}$ was resided from three sources, blood circulation $\mathrm{Ca}^{2+}$, intracellular $\mathrm{Ca}^{2+}$ and extracellular $\mathrm{Ca}^{2+}$ in wounded area $(35,36)$. In hematoma phase, the $\mathrm{Ca}^{2+}$ affinity with protein that transport is capacity and regulates ions that is important activities of cells accrose the plasma membrane. $\mathrm{Ca}^{2+}$ ions plays two roles in acceleration of wound healing, $1^{\text {st }}$ role when $\mathrm{Ca}^{2+}$ react with calmodulin with ATP, this phenomena is very important in cutaneous skin wound healing (37), while $2^{\text {nd }}$ rule of $\mathrm{Ca}^{2+}$ that react with sarcoplasmic reticulum occurs when $\mathrm{Ca}^{2+}$ influx from pump of $\mathrm{Ca}^{2+}$ channel and binding myosin and actin protein to initiate cytoplasmic bridges between two wound edges. $\mathrm{Mg}^{+2}$ ions don't had individual play role in collagen and fibers develop, therefore the histopathology in all groups no evidenent to $\mathrm{Mg}^{+2}$ had role without $\mathrm{Ca}^{2+}$ (12). Hydrogel was maintained the wound moist without contamination because of high sterile aqueous counting in hydrogel base (38).

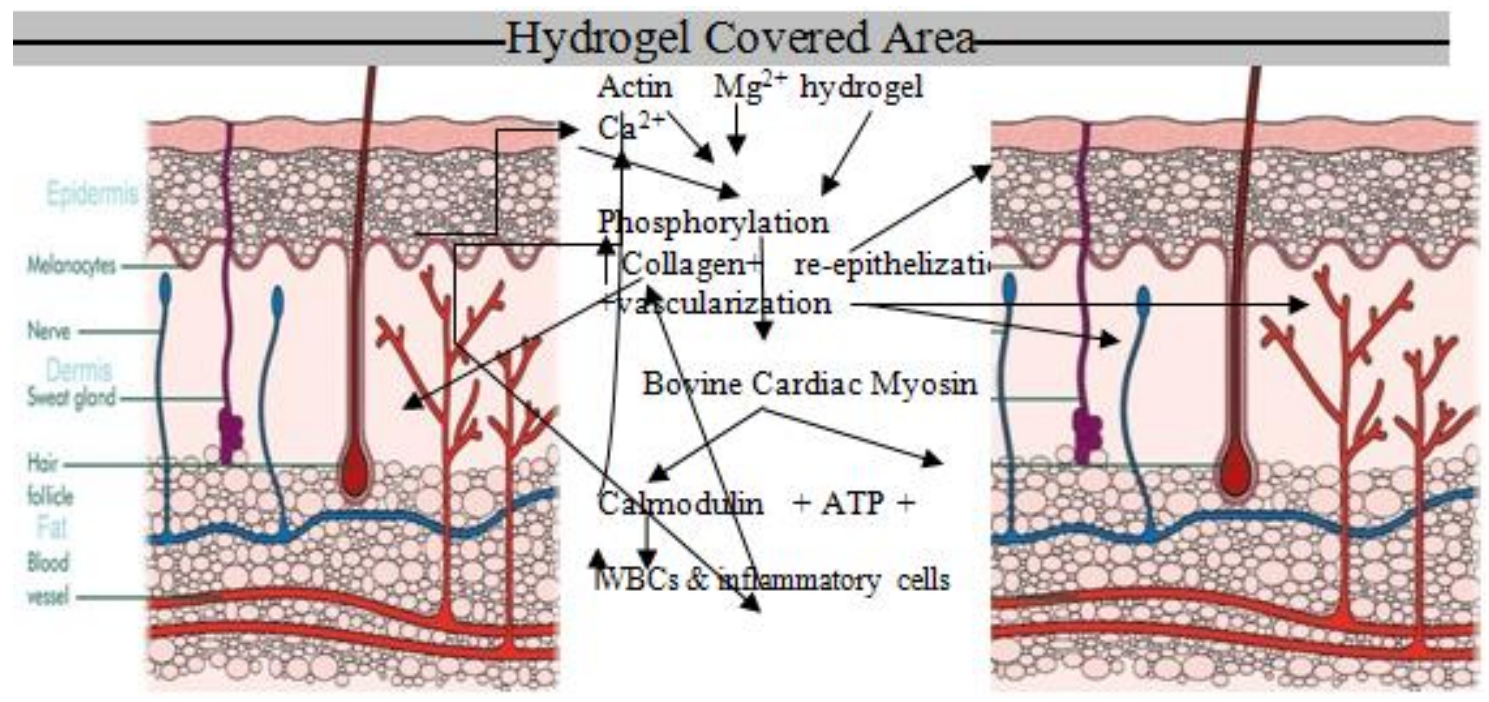

\section{Conclusion and Recommendation}

- The bovine cardiac myocin-hydrogel polymer improve wound edges biological processing as well as maintance the wound sterility.

- The polymer can applied to improve healing in tendon injury, bone fracture, nerve damage, and cartilage erosion.

\section{Acknowledgement}

I would like to thank Ali A Alrushud/ college of sciencesdepartment of chemistry /Basrah university.

\section{References}

[1] Babu GJ, Warshaw DW and Periasam M. Smooth muscle myosin heavy chain isoforms and their role in muscle physiology. Micro. Sci. Res. Techn. 2000. 50: $532-540$

[2] Delaneroll PM, Nishikawa DA and Yost RS. Increased phosphorylation of myosin light chain kinase after an increase in cyclic AMP in intact smooth muscle.Sci. Bio Chem. J. 1984, 223: 4120-4126.
[3] Gilbert R, Cohen JA, Pardo S, Basu A, and Fischman DA. Identification of the A-band localization domain of myosin binding proteins $\mathrm{C}$ and $\mathrm{H}$ (MyBP-C, MyBP-H) in skeletal muscle. J.C.Sci. 1999, 112: 6979.

[4] Freiburg A and Gautel M. A molecular map of the interaction between titin and myosin-binding protein C. implecation for sarcomeric assembly infamilial hypertrophic cardiomyopathy. Eur. J.Biochem. 1996. 235: 317-323.

[5] Gilbert R, Kelly MG, Mikawa T, and Fischman DA. The carboxyl terminus of myosin binding protein $\mathrm{C}$ (Myosin-C, MyBP-H) in skeletal muscle. J.C.Sci 1996, 109: 101-111.

[6] Rayment I. The structure basis of myosin ATPase activity. J. Bio. Chem. 1996. 271,27:15850-10853.

[7] Kulikovskaya I, McClellan R, Levine R and Winegard S. Effect of extraction myosin binding protein $\mathrm{C}$ on contractility of rat heart. Am. J. Physio. Heart. 2003.285: H857-H865.

[8] Sandri M, Rizzi C, Rossini K, Catani C, Catani M and Spina M. Purification of myosin heavy chain isoforms by electroendosomatic preparative gel electrophoresis 


\section{International Journal of Science and Research (IJSR) \\ ISSN (Online): 2319-7064}

Index Copernicus Value (2015): 78.96 | Impact Factor (2015): 6.391

: characterization of embryonic slow myosin heavy chain. Bas. Appl. Myol. 1999. 9,2: 71-79.

[9] Soong HK and Cintron C. Different corneal epithelial healing mechanism in rat and rabbit: role of actin and calmodulin. Inves. Ophth. Vis. Sci. 1985.28:838-848

[10] Sleep JI, Irving $M$ and Burton K. The ATPase hydrolysis and phospholation release steps control the time course of force development in rabbit skeltel muscle. J.Phsiol. 2005.563,3: 671-687.

[11] Stone DB, Mendelson RA, Botls J and Cheung PH. EPR and fluorescence depolarization studies on bovine cardiac myosin. AJP- Heart Circ Physiol.2011. 301,H514-H522.

[12] Burke M, Reisler E and Harrington. Myosin ATP hydrolysis : A mechanism involving a magnesium chelate complex. Pre. Nat. Acada. Sci.1973. 70,12: 3793-3796.

[13] Majumder P, Aranjuez G, Amick J and McDonald JA. Par-1 controls myosin-II activity through myosin phosphatase to regulate border cell migration. Curr. Bio. 2012. 22: 363-372.

[14] Kolega J. Asymmetric distribution of myosin IIB in migrating endothelial cells is regulated by a rhodependent kinase and contributes to tail retraction. Mol. Bio. Cell. 2003, 14: 4745-4757.

[15] Ahmed EM. Hydrogel: preparation, characterization, application, A review. J.Adv. Res.2015. 6: 105-121.

[16] Madaghiele M, Demitric C, Sannino A and Hmbrosis L. Polymeric hydrogel for burn wound care: advanced skin wound dressings and regenerative template. Burn Truma. 2004, 4: 153-161.

[17] Pelizzo G, Avanzini MA, Cornaglia AL, Osti M, Avolio L, Maccario R, Dominici M, Costanzo F and Calcaterra $\mathrm{V}$. Mesnchymal stromal cells for cutaneous wound healing in a rabbit model: pre clinical study applicable in the pediatric surgical setting. J Transl. Med.2015. 13: 219-235

[18] Pullar CA, Rizzo A and Isseroff RR. $\beta$-adrenrgic receptor antagonists accelerate skin wound healing. J.Bio.Chem. 2006. 281, 30:21225-21235.

[19] Piplelzadeh HM, Piplelzadeh MR and Husseinzadeh M. A study on the effect of molulation of intracellular calcium on excisional wound healing in rabbit. Ir. Bio. Chem.J. 2003. 7,3: 161- 166.

[20] Guo S and DiPietro F. Factors affecting wound healing. J.Dent. Res. 2010. 98,3: 219-229.

[21] Barden JA, Symons P, Cartmill JA, Miki M and Hambly BD. Extraction of myosin light chain and actin from bovine cardiac muscle acetone powder. Anal. Bio.Chem. 1986. 158, 258-288.

[22] Feuer G, Molnar F, Pettko E and Staub FB. The polymerization of proteins adenosine triphosphate and the polymerization of actin. 1950. 33, 3: 443-451.

[23] Philip L, Separavic F, Cornell A and Barden CG. Actin dynamics studies by sold-state NMR spectroscopy. Euro.Biophys. J. 1991. 19,3: 147-155.

[24] Kobayashi R, Goldman RD, Hartshorne DJ and Field JB. Purification and characterization of myosin from bovine thyroid. J.Bio.Chem.1977.252,22:8285-8291.

[25] Talaat HA, Sorour MH, Aboulnour AG, Shaalan HF, Ahmed EM, Awad MA and Ahmed MH. Development of a multicomponent fertilizing hydrogel with relevant techno-economic

indicator.

Am.Euras.J.Agri.Enviro.Sci.2008.3,5:764-779.

[26] Fish RE, Brown MJ, Danneman PJ and Karas AZ, 2008: Anesthesia and analgesia in laboratory animals. $2^{\text {nd }}$ ed. Elsevier Inc., 150-175.

[27] Quesenberry KE and Carpenter JW, 2011: Ferrets, rabbits and rodents: clinical, medicine and surgery. Elsevier Inc., 45-65.

[28] Tizard IR, 2004: Veterinary immunology: an introduction. $7^{\text {th }}$ edu. Saunders, 405-421.

[29] Bancroft JD and Gamble M, 2003: Theory and practical of histological technique. $5^{\text {th }}$ edu. Churdill Livingsongs, London and Toronto. 433-450.

[30] Sidhi SG, Mani H, Gaddipatti JP, Singh AK, Seth P, Banandha KK, Panaik GK, Maheshwari RK. Curcumin enhances wound healing in streptozotocin induced diabetic rats, wound repair regeneration. $\mathrm{Br}$. J. Plast. Sur. 1999,7: 362-368.

[31] Bertet C, Sulak L, Lecuit T. Myosin-dependent junction remodeling controls planar cell interaction and axis elongation. Nature Phy. J. 2004, 29: 667671.

[32] Terry SJ, Elbediwy A, Zihni C, Harris AR, Maryse B, Charras GT, Bald MS, Matter K. Stimulation of cortical myosin phosphorylation by p114RhoGEF drived cell migration and tumor cell invation. PLOS. 2012,7(11) :e50188-1-8.

[33] Ojingwa JC, and Isseroff RR. Strategies of $\beta$ adrenergic receptor antagonists accelerate skin wound healing. J Investig. Dermatol. 2003, 121(1): 1-12.

[34] Cha J, and Falanga V. Stem cells in cutaneous wound healing. Clin. Dermatol. 2007, (25): 73-78.

[35] Gackiere F, Bidaux G, Lory P, Prevarskaya N, Mariot $P$

A role for voltage gated T-type calcium channels in mediating "capacitative" calcium entry Cell Calcium. J Br Biochem. 2006, 344-351.

[36] Resende RR, Da Costa JL, Kihara AH, Adhikari A, Lorencon $\mathrm{E}$ Intracellular $\mathrm{Ca} 2+$ regulation during neuronal differentiation of murine embryonal carcinoma and mesenchymal stem cells. Stem Cells Dev. 2010, 19:379-394.

[37] Grewal SS, Fass DM, Yao H, Ellig CL, Goodman RH, Stork PJ. Calcium and cAMP signals differentially regulate cAMP-responsive elementbinding protein function via a Rap1-extracellular signal-regulated kinase pathway. J. Biol. Chem. 2000 (3) ; 275(44): 34433-41.

[38] Jian H, Zhiming H, Yongzhong BA, and Zhixue WE. Thermosensitive poly $(N$-isopropylacrylamide-coacrylonitrile) hydrogel with rapid response. Chinese J Chem Eng., 2006, 14(1) : 78-92. 